\title{
Why Not Escape? On the Hosiotes in Plato's Crito
}

JOANNA KOMOROWSKA / Warsaw /

\section{The swarm of questions}

Why does Socrates drink his hemlock? What motivates his rejection of Crito's proposal to escape? These and similar questions concerning the decision made by the philosopher gave rise to a considerable number of scholarly inquiries as well as to a whole array of answers. Thus, Greenberg (1965) sought the explanation in Socrates' "heroic temper", while Barker (1977) argued for the decisive role of the philosopher's elevated moral awareness. Importantly, a great deal of scholarly discussion builds on the apparent incompatibility of two accounts of civil duties in the Apology and Crito. In the Apol$\operatorname{ogy}(29 \mathrm{c}-\mathrm{d})$, we see Socrates challenge his audience and, in fact, the judges with the declaration that he will under no circumstances renounce philosophy, and that he will continue his instructing the Athenians. In the Crito, the philosopher chooses to reject his friend's offer of help, and, when doing so, he implicitly accepts the death sentence. ${ }^{1}$ Whilst the two dialogues are often regarded as inconsistent, various attempts to explaining the inconsistency resulted in an impressive number of publications devoted to the

${ }^{1}$ Quotations from the Apology and Crito in C.D.C. Reeve's (2005) translation. Other works quoted as they appear on the Perseus Project database. 
issue. ${ }^{2}$ The present paper will seek to contribute to this line of inquiry. When trying to ascertain why Socrates chooses to die, the article will suggest that taking into account the then Athenian customs and rituals may contribute to a better understanding of the dialogue. My primary assumption, an assumption shared with many works on the Crito, is that the dialogue is naturally connected with the Apology and, (albeit possibly less closely), with the Euthyphro. ${ }^{3}$ After all, Socrates' death is, at least in Crito's eyes, a "natural", though avoidable, consequence of his trial.

\section{The context}

It seems rather uncontroversial to assume that the arguments in the Crito necessarily relate to those of the Apology. ${ }^{4}$ We know that one of the two charges brought against

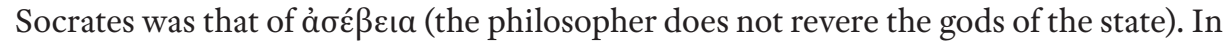
sharp contrast to this, Socrates insists during his defense that all his philosophical activity was conducted in service to the Delphic god. Thus, he claims that it was a fulfillment of his divinely sanctioned mission and, thereby, an act of piety. Hence, he purports not only that his philosophical activity was agreeable to the gods, but also that refraining from it would have been tantamount to disobeying the divine command, and, thereby, to committing an act of impiety (this may constitute a link with the Euthyphro, a dialogue expressly dealing with the nature of pious and impious acts).

Consequently, in the Apology, Socrates' persistent questioning of the established norms and his apparent disrespect for the Athenian authorities is portrayed as a divine mission: it is supposed to constitute an act of utmost piety. ${ }^{5}$ The question returns in the Crito, the dialogue which in its own way may contain an implicit answer to the fundamental question posed by the Euthyphro, but at the same time, responds to the charge leveled against the philosopher. In a striking tour de force, Socrates' rejection of Crito's escape plan, a rejection which entails acceptance of the death sentence, becomes an act

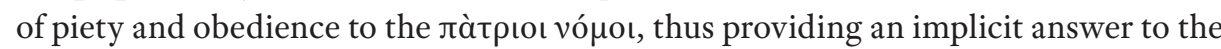
dilemma of the Euthyphro.

2 The contribution by Kraut (1984) is probably the most important one.

3 I do not wish to regard the three as a continuous "story", or to view the Crito as nothing more than a follow-up on the Apology. The three dialogues are certainly linked by the setting (as far as they deal with the legal turmoil resulting in Socrates' death); moreover, they also share a deep concern for the issue of justice (as far as they deal with the problem of just conduct, the relation between justice and piety, etc.). Yet, they do not form a unified and continuous structure: there are diverse subtle shifts in focus and numerous perplexing discrepancies. Consequently, the three dialogues should rather be perceived as a trilogy rather than a unity.

4 There seems to be, however, an important point that separates Apology from all other dialogues: the subject and the very mise en scene of the Apology are limited and defined by everything that actually took place in the court. Thus, we may assume that the main features of Socrates' speech reflect those of the actual apology. In the Euthyphro and Crito, on the other hand, the limitations are considerably fewer, and we may expect more creativity on Plato's part.

5 The point is made repeatedly in the dialogue, most clearly in the already mentioned Apol. $29 \mathrm{c}-\mathrm{d}$. 
Even from a purely literary point of view, this is a masterly move, as the acceptance of the verdict undermines its very foundation: Socrates' death and his obedience to the laws effectively undercuts the impiety charge. Also, it refutes the charge of corrupting the youth: while the philosopher dies in obedience to the verdict, he at the same time recognizes the authority of the Athenian institutions. When embracing death, Socrates appears to recognize a consummate obligation that binds him to the land and its gods. We shall return to this in the course of our further considerations.

\section{The duties of an Athenian}

While Richard Kraut's magisterial work Socrates and the State is clearly the most comprehensive treatment of the dialogue, it elies on several assumptions that can be challenged. Indeed, several important objections were raised by Bostock (2005: 221-223). As for myself, I would like to add two more reservations. First of all, Kraut's treatment assumes that the lack of references to the ephebic oath before the fourth century BC entails that there was no such thing in Socrates' youth, and thus that the wording of the oath has no bearing whatsoever on the argument contained in the Crito.$^{6}$ The other assumption, a point well noted by Ober, concerns the identity of the Laws as they appear to the philosopher: Kraut seems to reject the possibility that what we we are dealing with here is an incarnation of the actual laws of Athens, i.e. the result of $399 \mathrm{BC}$ vote.?

As for the first assumption, even though we have no evidence to support a claim that the oath was necessarily functional at the time of Socrates' death, one has to allow for the impact it might have had on the Athenian understanding of the Platonic dialogue at the time of its composition. ${ }^{8}$ Similarly, I assume that regardless of the exact time of its introduction into the Athenian usus, the oath specified the general expectations that the political body of Athens had of its members and that the image of citizen it promoted reflected the more general and widespread preconceptions of 'a good Athenian'. ${ }^{9}$ One

${ }^{6}$ Compare Kraut 1984: 152, n. 1.

7 On the issue see Ober 1998: 187, n. 59. Interestingly, the issue attracted some attention in the work of Harte (2005), who noted that the identity of the Laws seems to fluctuate and change from the actual laws to the more generalized, postulative entity. The issue at stake is complicated by the date of the dialogue: at the time of

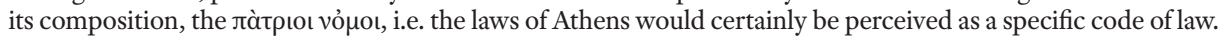

${ }^{8}$ For a study of the presence of the oath in the fifth-century Athens compare Siewert 1975. For a possible influence of the oath on the Platonic portrayal of the trial of Socrates (more precisely, on Apology $28 \mathrm{~d}$ 6-29 a 1) see Margalit Finkelberg's Plato Apology 28d6-29a1 and the ephebic oath, of which an outline is available online at the following address: http://www.apaclassics.org/AnnualMeeting/05mtg/abstracts/Finkelberg.html(accessed 15 Nov. 2011).

9 Lycurgus' Against Leocrates provides us with an interesting passage: “It was for this reason, gentlemen of the jury, that all the Greeks exchanged this pledge at Plataea, before taking up their posts to fight against the power of Xerxes. The formula was not their own but borrowed from the oath which is traditional among you. It would be well for you to hear it; for though the events of that time are ancient history now we can discern clearly enough, in these recorded words, the courage of our forbears" (80). Manifestly, the speaker relates the formula used in $479 \mathrm{BC}$ to an ancient paradigm: surviving in the speech, the oath secures obedience to the leaders in battle, steadfastness, piety and, interestingly, remembrance of the danger the barbarian threat posed to Greek 
may also note that the political upheavals of the late fifth century, with the introduction of the oligarchic rule and, even more importantly, with the oppression wrought by the Sparta-sponsored tyrants, would have resulted in particularly pronounced emphasis on an image of model citizen: the reviewing and promulgation of the Athenian law code at the very close of the century ${ }^{10}$ involved, after all, an immense effort of political and juridical reflection and one may imagine that the process would be performed with the view to securing a well-functioning and stable political organism as well as with the view to influencing and shaping the behavior of citizenry in an well-defined manner. To put it differently: any review and promulgation of the Athenian laws would be effective and, indeed, possible only if the politicians made several assumptions concerning the citizenry,

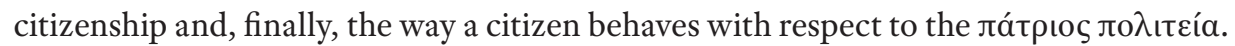

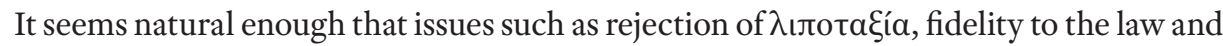

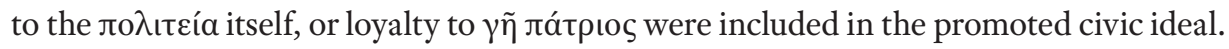
Furthermore, it seems reasonable to assume that this ideal would stand very much the same throughout the Classical period.

Now, the ephebic oath was handed down to us in the following form: ${ }^{11}$

The ancestral oath of the ephebes, which the ephebes must swear. I shall not bring shame upon the sacred weapons nor shall I desert the man beside me, wherever I stand in the line. I shall fight in defence of things sacred and profane and I shall not hand the fatherland on lessened, but greater and better both as far as I am able and with all. And I shall be obedient to whoever exercise power reasonable on any occasion and to the laws currently in force and any reasonable put into force in future. If anyone destroys these I shall not give them allegiance both as far as is in my own power and in union with all, and I shall honour the ancestral religion. Witnesses: the Gods Aglaurus, Hestia, Enyo, Enyalios, Ares and Athena Areia, Zeus, Thallo, Auxo, Hegemone, Heracles, and the boundaries of my fatherland, wheat, barley, vines, olives, figs.

The oath, intended to preserve the democracy in its Athenian form and, naturally enough, to preserve the Athenian state itself, was sworn by male Athenians on the brink of their adulthood and, as it is manifested by the wording, spelled out the city's expectations with respect to its citizen body and, by implication, the most basic duties a citizen had toward his jó $\lambda$ ıs. One notes that the ideas contained in its wording are well attested in the fifth century literature ${ }^{12}$ a circumstance manifesting the essential universality of

freedom. Clearly, the provisions securing steadfastness in battles and observance of burial (and hence, religious) customs remain of paramount interest at that point, as does the very fact that Lycurgus invokes something like an established custom.

${ }^{10}$ On the 410-399 BC revision compare Hansen 1999: 172-175 and, briefly, Ober 1998: 186-187.

11 The text is quoted as it appears in P.J. Rhodes and Robin Osborne, Greek Historical Inscriptions 404-323 BC (Oxford, 2007). For a discussion of the text see also Siewert 1977.

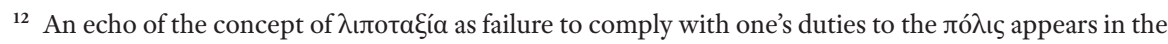
Euripidean Phoenissae 991-1005 and Erechtheus f. 360 Cropp. The idea that a true citizen takes an active interest in the concerns of the city goes back to the Solonic law (with regard to latter compare the recent discussion of Van't Wont) and is manifestly present in Periclean epitaph (Thuc. II 37), while an acute rejection of those who 
the formula. Indeed, even if the actual oath was unknown earlier, its wording reflects something of the deeply felt attachment to the inherited tradition, to the land and its vó $\mu$ o so famously applauded in the funerary speech of Pericles when speaking in honor of the fallen during the first year of the Peloponnesian war. ${ }^{13}$ One should remember that the very sentiment that every citizen should strive to preserve and uphold the democratic

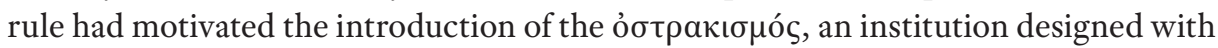

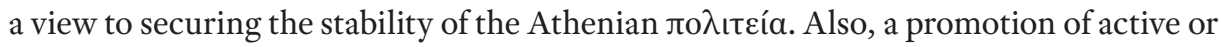
conscious citizenship understood as responsibility toward the лó $\lambda$ ı rather than any other nuclear entity is quite likely to figure among the reasons motivating the Kleisthenian division of $\varphi v \lambda$ aí. Equally importantly, Solon, often considered to be the founding father of the Athenian лолıтвía, emphasized the importance of civil interest in the communal (political) welfare when banning neutrality in case of civil war: a citizen must take interest in the matters affecting their лó $\lambda$ ıs. ${ }^{14}$ Indeed, even if we admit that the oath as it is known from the Acharnian inscription was absent from the earlier political sphere, we are far from lacking evidence that it describes the civic ideal well known in the earlier epoch. Moreover, even if we reject the idea of its earlier introduction, it is still tempting to link the emergence of its canonized form into the Athenian public life with the rewriting of the law code. Thus understood, the oath becomes a visible symbol of the renewed order of the polis and democracy resurrected after the fall of the Thirty.

\section{The lawful verdict}

What we have to understand is that Socrates, as portrayed in Crito, has been sentenced to death in the formal court of law, the verdict supported by the vast majority of the chosen jurors. Hence, in the eyes of the law, as it governs the Athenian state and as it has been accepted by the citizen body, he did deserve the punishment. Furthermore, he failed to persuade the court that his guilt could be assuaged by anything less severe than the capital punishment. The lawful verdict has been returned and he is about to die. There is nothing to save him, except for the escape, the possibility of the latter being arranged by his friends and involving, as it stands, an act of corrupting a public servant. As Crito strives to persuade Socrates to choose the latter solution, and as the philosopher attempts to

transgressed against the state is mirrored in the fate of Megacles' party as described by Plutarch (Solon XII 4). For the loyalty to the legal order of the city see the insightful comment of Gagarin (1986: 80): "[...] the very fact of enacting a set of laws for a particular polis would enforce the idea that those who belonged to that polis were specially characterized by an obligation to obey those laws as well as by a claim on the protection offered by them."

13 Compare Thuc. II 37.

${ }^{14}$ On the rule, compare Plu., Solon, 20. Characteristically, the communal, or political reasons underlying the norm do not go unnoticed by the Cheronean, who notes: "He wishes, probably, that a man should not be insensible or indifferent to the common weal, arranging his private affairs securely and glorying in the fact that he has no share in the distempers and distresses of his country, but should rather espouse promptly the better and more righteous cause, share its perils and give it his aid, instead of waiting in safety to see which cause prevails." 
persuade his friend to desist from his quest, the discussion turns inevitably to the important issues of justice, lawfulness, legal order, and to the relation between a man and their community. Due to the peculiarities of the setting, it becomes a debate which contrasts self-preservation and upholding of the law, the contrasting expectations which a household and the community have with regard to an individual. ${ }^{15}$ And it is into this debate that Socrates introduces the Laws themselves, the Laws 'as they are', indeed, the Laws as these are to be obeyed by every Athenian citizen, the contract cemented by an oath, ${ }^{16}$ with its inherent formula: And I shall be obedient [...] to the laws currently in force and any reasonable put into force in future. ${ }^{17}$ To escape obedience of a legal norm and to remain a model citizen an individual would either have to try and change the norm in question or, in cases posing a particular danger to the community, to try and abolish the contested

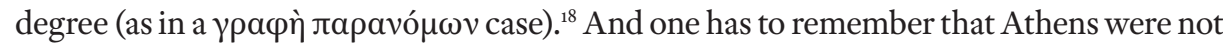
adverse to change, provided it could be persuasively defended: there was an established review process, intended to secure the renewal and the effectiveness of the legal system, while considerable care was exercised when securing the official and intrinsically legal ways in which an individual could contest the law, he deemed damaging or unjust. And by the Athenian standards, if such a claimant failed to achieve his objective (i.e. failed to persuade the assembly about the unjust, damaging or corruptive nature of the given legal norm), then he had to conform to the existing legal order.

For Crito, as for many, it is the justice of the verdict that counts. Considering the sentence to be substantially wrong, he is inclined to ignore its formal validity and argues for Socrates' escape as for a perfectly justified option (this, however, means that he accepts the principle effectively rejected by Socrates, i.e. he assumes that acting unjustly is justified if one is acting in response to some injustice $\left.{ }^{19}\right)$. For Socrates' embodied Laws (regardless of the problem concerning the identity of their views with those of the philosopher, or, for that matter, of the fact that the Laws would probably be in agreement

15 These peculiarities are well stressed by Ober (1998: 179) who duly emphasizes the finality of the choice (the discussion cannot be repeated at another time), and also pays some attention to the impact of the physical setting of the scene, located within the confines of the "public place" (to demosion, i.e. prison).

${ }^{16}$ It was certainly strengthened by the oath in the times of Lycurgus, who could proudly claim in his Against Leocrates: The power which keeps our democracy together is the oath (79). His prosecution of Leocrates reflects the pro-civic ideology of his times, and openly supports the belief that citizen's duty toward his country is to be considered sacred and, moreover, that the welfare of the political community is dependent on the effort of every single member.

17 One notes that the custom of confirming the legal constitution of Athens with an oath dates back to the Solonian constitution, compare Arist. Const. Ath. 7: "he established a constitution and made other laws, and they ceased to observe the ordinances of Draco, except those relating to homicide. They wrote up the laws on the Boards and set them in the Royal Colonnade, and all swore to observe them."

18 Compare Ober 1988: 186-187, Hansen 1990: 171-185. A process by which a law was officially challenged is described by Demosthenes (24. 20-23).

19 An additional complication may be related to the fact that Socrates' choice would be made on deliberation: while acting unjustly under the onslaught of an emotion (particularly anger) would be regarded as understandable even if inconsiderate (indeed, it is generally thought that anger forms a natural response to what is perceived as unjust), committing an injustice upon deliberation is far from acceptable throughout Greek history (on the issue compare Konstan 2006: 41-77 and Harris 2002: 339-362. 
with Crito as far as the limited ban on wrongdoing is concerned ${ }^{20}$ ), the situation is vastly different: since the formal requirements have been satisfied, they argue in favor of suffering the imposed penalty. In defense of their stand, they invoke the so called contractual argument, emphasizing the claim a лó $\lambda$ ıৎ̧ has over its citizen who was effectively reared and nurtured within the framework of its political and legal order. ${ }^{21}$ Also, they invoke the consensual argument: by choosing not to leave Athens and to conduct all his business in the city Socrates agreed to uphold the legal order of his лó $\lambda$ ıc. Moreover, he had his sons brought up in the same political milieu, thus, proclaiming his approval of the respective

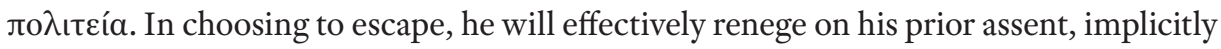
rejecting the validity of the political order he manifestly embraced throughout his life, an act constituting a breach of the universally acknowledged bond between a citizen and its city. Viewed against the mirror of the fifth century literature, an individual acting on an unshakeable belief in his righteousness and proclaiming himself exempt from the rule of the law because of the alleged superiority of his understanding remains not only a highly problematic figure, but also a challenge to the democratic system, and, possibly, a threat to the society that breeds him. ${ }^{22}$

\section{The tragic link}

We know Plato to have been well acquainted with the then tragic literature - several of his dialogues remain deeply indebted to the Euripidean drama: ${ }^{23}$ perhaps it would be worthwhile to consider the possibility that both Socrates and Plato take a stand in a political debate manifesting itself in tragedy. ${ }^{24}$ This entails considering the Crito against the mirror of the Sophoclean drama and comparing Socrates with a heroic protagonist of Antigone's type: a person whose sense of rightness induces her or him to challenge the acknowledged legal order. ${ }^{25}$ The Sophoclean hero, standing to some

20 On the issue compare Harte 2005. It is worth emphasizing that I share Harte's reservations concerning the genuineness of the Laws' speech - it is at best risky to assume that their speech reflects Socrates' own views merely on the grounds of his having introduced the Laws into his considerations.

${ }^{21}$ Since the intricacies of the argument were discussed by Kraut (1984: 115-148) it seems hardly necessary to indulge in a similar discussion at this point.

${ }^{22}$ Knox (1964) remains a fundamental work on the problem. His emphasis is on Sophocles and the unbending character of the latter's heroes; yet, it is easy to understand that moral superiority would always remain a problem in a city which claimed to rely on the will of the many.

${ }^{23}$ The dependence is particularly pronounced in the Gorgias (on the issue compare Nightingale 1992), but transtextual references are not uncommon in the other dialogues.

${ }^{24}$ The possibility is emphasized by the Laws' description of the evil of exile, a description making a considerable use of a number of topoi attested in the fifth century literary work. Thus, the image of exile as tantamount to slavery (53 e: live by currying favor with every man and acting the slave) revokes Polyneices' description of his fate in the Euripidean Phoenissae 389-407. Characteristically, losing freedom of speech (parrhesia) is mentioned as the very worst consequence of an exile (Pho. 391) and, subsequently, as a feature of slavery (by Jocaste in v. 392).

25 One has to remember that the prohibition of a burial as applied to deceased traitors was not unknown in Athens. In fact, it formed a recognized practice (one may mention the fate of Megacles' followers, as described 
extent apart from the masses, remains a law unto himself: his unyielding maintenance of the norms he considers superior to any edict promulgated by man creates a crisis that ultimately destroys him or herself and deeply affects the community concerned. In the essence, however, such a hero is unable to act in any other way: Ajax, as long as he is Ajax, cannot accept the unanimous verdict of the army, whereas Antigone, being Antigone, cannot yield to Creon's demands. The very inflexibility of their moral stand is an element mirrored in Socrates' adamant upholding of the choices he has made in his life, such as, to adduce the possibly most famous example, his refusal to obey the court should the latter acquit the philosopher, but made the acquittal dependent on his renouncing the practice of $\varepsilon \lambda \lambda \varepsilon \gamma \chi 0 \varsigma$ (Pl. Ap. $29 \mathrm{c}-30 \mathrm{c}$ ). Yet, symptomatically, his decision is made (unlike those in the Sophoclean drama) with a view toward the good of the community, indeed, with a view of 'making people better'. Thus, the important point is that unlike the Ajaxes or Heracleses, Socrates chooses to destroy himself rather than the norm and the polis, and. Thus, his act of heroic defiance leads him to stand by the legal order of the city (or, depending on the reading, by his own moral ideal) even as the decisions of the latter prove to be his undoing. ${ }^{26}$

This, however, is not all: his hypothetical defection could wreck the city, as it would provide an example of one who deems himself above the law, or at the very best, an example of one who refuses to recognize the authority of a lawfully passed sentence. ${ }^{27}$ This is not a mere detail, even if we agree that the city will not suffer damage unless a notably larger number of citizens choose to disregard its legal order. ${ }^{28}$ Still, we do know, for Socrates is quite emphatic on this point both in the Apology and in the Crito, that his whole adult life was dedicated to educating the Athenians. ${ }^{29}$ This education was his divinely ordained mission, an act of deep piety - both with regard to his homeland, which he sought to make better (as it was a duty of every citizen, as clearly stated in the surviving text of the oath), and with regard to the gods, on whose authority he was acting (in conformity with the 'honour the ancestral religion' postulate). Ironically, the quest resulted in the impiety charge. Yet, the question seems to be, whether enouncement of the law (as manifested by rejecting the death sentence) would contribute to a Verbesse-

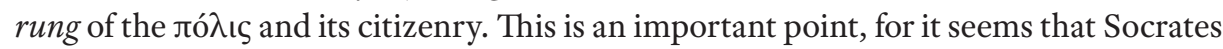

by Plu., Solon, XII, 4). Hence, it is rather Antigone's refusal to conform to the norm that stands out in the play.

${ }^{26}$ In essence, neither Antigone nor Ajax recognizes the authority of decisions they consider unjust: meanwhile, Socrates seems to recognize the legality and the authority of the sentence even if he considers it unjust (which is also true of his personified Laws).

${ }^{27}$ Now, one has to appreciate the weight of this possibility: the person most famously believed to be exempt from the legal order of his own country is the Persian king (as portrayed in the Aeschylean Persae).

${ }^{28}$ It is in this respect that one has to consider the possibility that in escaping, Socrates will do 'his utmost' to harm the city, that the damage to the legal order will be such as it is in his power to inflict - a point highlighted by Barker (1977) that brings to mind the formula used, albeit in reference to military effort, by Lycurgus, in Leocr., 63-64.

${ }^{29}$ Indeed, in the Apology he refuses to desist from his strivings even if such a renouncement were to guarantee his being acquitted (one has to remember, however, that his declaration is rendered empty by the intricacies of the Athenian court system: there is no possibility of one being released from charges brought against him on the condition of an appropriate behavior in the future, a point rightly stressed by Kraut 1984: 13-17). 
strives to persuade Crito that his death is an act of piety on par with his past search for the sage and the $\varepsilon \lambda \varepsilon \gamma \chi \chi \varsigma$ practice. As it was in the case of the impiety charge, there is a profound irony to the issue: contrary to every expectation the polis stands to gain by loosing Socrates, not by keeping him alive (which seems to be his point in the Apology)..$^{30}$ Similar irony underlies the circumstance mentioned by the Laws themselves: any attempt to avoid the sentence once it has been passed (its justice, one should remember, is not at issue - the Laws actually admit that the guilty verdict was materially unjust) will effectively furnish an incontestable proof of Socrates' guilt. ${ }^{31}$

At this point, it might be useful to invoke the principal issue of the Euthyphro, the dialogue that leads the two participants into massive disagreement on the subject of piety. But is it only piety that is at stake? Euthyphro reports his father because of this latter's responsibility for a slave's death (actually for a murderous slave's death). Being left to starve, bound and at the mercy of the elements, the slave died in circumstances strikingly redolent of the Athenian apotympanismos, ${ }^{32}$ suggesting that the issue at stake might be the neglect of the legal process when meting out the punishment. ${ }^{33}$ Thus, the dialogue highlights certain complications intrinsic in a legal system, a system in which what is lawful interferes with what is just. Euthyphro's actions are surely lawful: the problem is how they can be just, if, at the same time, they effectively violate the common assumptions concerning the father-son relationship. The latter is an interesting point, for the Laws will invoke the very relationship in their address to Socrates in the Crito. ${ }^{34}$ Yet, while the point is worth discussing, such a discussion will have to be postponed: for now it suffices to note that the legal vs. just debate reverberates throughout the three dialogues, the conflicting obligations being of paramount importance for their respective debates. Also, the Euthyphro introduces the religiosity theme: what may be termed religio legis in the Crito was effectively foreshadowed by the religio deorum undercurrent in both the Apology and the Euthyphro.

30 To this one could add another point: in the Apology Socrates attaches a considerable importance to the sudden silence of his $\delta a \mu$ óvıov, the internal voice that used to keep him from any harm (in the sense of "harm for Socrates himself", i.e. his committing injustice). By contrast, he emphasizes the divinity of the 'elenchus' command, the part played by a deity in life-choices. This may lead one to consider the guilty verdict as being to some extent a part of the universal pattern of things, to be judged by gods alone. In such a case, the personified Laws may be taken to be a manifestation of a daimonic voice (after all, their intervention is negative one, for they aim to prevent Socrates from doing something rather than to persuade him to do something), hence the voice warning Socrates away from a possible injustice (a possibility strengthened once we consider the wording of Crito 54 d: "this is what I seem to hear, as the frenzied dervishes of Cybele seem to hear the flutes, and this sound of these words re-echoes within me and prevents my hearing any other words"), and death comes as a continuance of a duty imposed by Apollo in Delphi.

$31 \mathrm{Pl}$. Crito $53 \mathrm{~b}-\mathrm{c}$ : "You will also confirm your jurors in their opinion, so that they will think they judged your lawsuit correctly. For anyone who undermines laws might very well be considered a corruptor of young and ignorant people." In a way, the reference to something like 'the general opinion' or 'people's opinion' mirrors Crito's concern for his own good name, thus constituting an implicit answer to the related argument (cf. Pl., Crito, $44 \mathrm{c})$. Yet to limit oneself to this interpretation alone seems somewhat simplistic.

32 Compare Gernet 2004.

33 And, as argued by Allen (2000: 18-19), this neglect could be considered criminal.

${ }_{34} \mathrm{Pl}$., Crito, $50 \mathrm{~d}$ sq. On the importance of the nurture issue compare below. 


\section{The military link}

Next, it might be said that Socrates' rejection of the escape plan bears traces of refusing an option similar to $\lambda$ เлота乡́la, desertion from one's post. It is important to understand that abandoning the latter forms a danger to every single soldier in the line and, hence, throughout classical antiquity it was perceived as a major crime against one's city. ${ }^{35}$ Literally, $\lambda$ ıлота乡́la means an escape from one's designated post in the battle, hence, given the peculiarities of the pedestrian army, the destruction of $\varphi a ́ \lambda \alpha \gamma \xi$ expresses damage both to those neighboring in the line and to the tactical arraignment of the army in general.

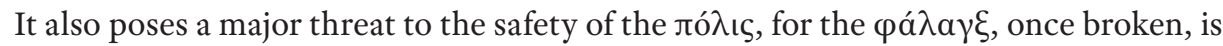
particularly hard to reassemble, a circumstance that made its stability into a considerable concern to both lawgivers and politicians. ${ }^{36}$ As Plato emphasized Socrates' military experience in other dialogues, and, most tellingly, in the Apology itself (28 e), we may safely assume that such an analogy would come quite natural to the minds of both the author and his hero ${ }^{37}$. Strikingly, in Socrates' defense speech the military simile serves to emphasize the obedience and loyalty versus the divine command, thus, endowing the thankless task of 'making people better' with a military luster. Here, in contrast, it acquires a meaning far more literal, referring to the actual abandonment of Athens understood as a destined post in battle. Thus, while a refusal to follow the established and recognized legal order becomes tantamount to an act of defection, the consequences of the latter appear more tangible: an act of disobedience constitutes a breach in the legal defenses securing the city's welfare. Like a chink in otherwise splendid structure it harms the whole, but, possibly more importantly, it ultimately harms the perpetrator. ${ }^{38}$ Regardless of the superiority so characteristic of Socrates' moral stand as described by Barker (1977), ${ }^{39}$ this point would probably be clear to both Crito (the internal addressee of Socrates' argument) and to Plato's reader (the external audience of the dialogue). Consequently, it may be argued that it is always wrong to harm the existing order - wrong objectively and from

35 One may invoke Lycurgus, In. Leocr., 63-64: "For if they admit that he deserted his country, once they have granted this, let them leave it to you to determine the seriousness of the offence; and even if he has committed none of these crimes, surely it is madness to say that this one man could cause no harm. Personally, gentlemen, I think the opposite is true: the safety of the city rested with this man. For the city's life continues only if each one guards her by personally doing his duty and if a man neglects his duty in a single aspect, he has, unwittingly, neglected it entirely."

36 On the importance of the phalanx and its contribution to Greek political thought compare Bravo \& Wipszycka-Bravo 1988: 189-211.

${ }^{37}$ In the Apology the mention of Socrates' military experience may be endowed with a particular importance: the áotpatcía forming a standard rebuke against active politicians, who were frequently seen as actively avoiding military duty, a mention of honorable performance in battle emphasizes Socrates' claims concerning political/juridical inexperience (on the issue of áotpatcía compare Christ 2001).

38 One is reminded of Socrates' paradoxical assertion in the Apology, where it is claimed that the Athenians, though persuaded the harm was his, were ultimately harming themselves (Pl. Apol. $30 \mathrm{c:}$ "For know that if you kill me, I being such a man as I say I am, you will not injure me so much as yourselves").

39 It must emphasized that I agree with his conclusion that the principal reason for Socrates' rejection of

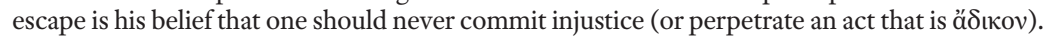


the 'egoist' point of view. ${ }^{40}$ Clearly, this condemnation is not leveled at just any attempt to question that order - yet, there are acts so harmful in their nature that they are entirely unacceptable (treason, desertion, sacrilege). Further, a fact of particular importance given the occasional reservations expressed by modern scholars, one may infer that there are also persons of such moral stature that even their minor concessions to what remains unsanctioned would count as harmful to the community (due to the very circumstances so aptly described in the Apology, Socrates is such an individual). ${ }^{41}$ Additionally, one may consider the Socratic argument as a mirror image of the principle famously invoked by Athens' original lawgiver, Draco in whose opinion all transgressions were tantamount to a breach of the established order. If we recall that the citizen body of fourth centu-

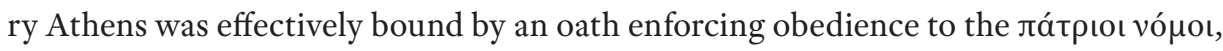
a transgression against the sworn law would be seen as an act of oath-breaking. After all, to quote the fourth century orator, Lycurgus: "The power which keeps our democracy together is the oath. For there are three things of which the state is built up: the archon, the juryman and the private citizen. Each of these gives this oath as a pledge, and rightly so" (In. Leocr., 79). Hence, in breaking the law, one effectively violates the agreement with the $\theta \varepsilon o i ̀$ лátpıı, i.e., the gods who witnessed one's pledge, thus committing an act of intrinsic impiety, ${ }^{42}$ an act all the more impious, if one's acts violate the express provisions of the previously given oath. This fact is of considerable significance if we try to uncover Socrates' motivation. As he was charged with impiety, it seems important that his choice allows him to escape a behavior that would be perceived as impious by the Athenian public: to perjure yourself is, after all, an impiety par excellence, and perjury could be taken as a conclusive proof of the charge leveled against the philosopher. ${ }^{43}$

As I tried to indicate above, a conscious transgression against the legal order understood in the radically Athenian terms may be regarded as the summa of all harm that may be inflicted on the city by an individual, a perspective which necessarily influences the actual perception of Socrates' possible escape. And as the ancient sources support the claim that individual acts of disobedience may be regarded as damaging to the legal structure of the polis, ${ }^{44}$ the modern reservations seem weakened - even though we may wonder whether the Crito does not implicitly question this accepted truth in describing

40 The latter view is supported by Penner (2005: 187-188) who forcefully advocates the teleological reading of the Crito, as firstly, consistent with the disobedience threat formulated in the Apology, and, secondly, compatible with Socrates eudaimonistic philosophy.

${ }^{41}$ At this point it seems particularly important to recall that we are dealing with Plato's rendition of the events leading to his teacher's death.

${ }^{42}$ It is crucial to note that for Lycurgus, divine wrath descends on perpetrators of any crime, not only those guilty of attempting to overthrow the democratic rule (In. Leocr., 79)

43 Compare Mikalson (1991: 167): “To commit perjury was 'to sin against gods' (S. frag. 472R) and might suggest that the perjurer no longer held conventional beliefs about the gods."

${ }^{44}$ Certainly, we know that the view advocating individual's responsibility regarding the preservation of the established politeia is not something foreign to Plato's own philosophy: after all, he would have no discordant voices in his ideal city. The Crito's connection with the other dialogues of Plato receives some attention in Sauvé-Meyer 2009: 374-375. 
the Laws as buzzing in Socrates' head and, thereby, obliterating any argument to the contrary. In the end, a concern for the city he served throughout his life wins the day and Socrates decides to die in his obedience to the verdict decreed by the citizen body, the same body that he strove to defend through his valor and improve through his elenchus.

\section{Conclusions}

To summarize: it is my belief that from a cultural perspective, there is no contradiction between the claims made in the Apology and in the Crito. Socrates hypothesized refusal to renounce philosophy ${ }^{45}$ and his actual refusal to embrace unjust means of saving his own life constitute two facets of a deeply pious attachment to the divine. After all, in his chastising the Athenians, the philosopher obeyed a divine command. Now, he refuses to violate an arrangement that may be perceived as sanctioned, and certainly witnessed by the gods. The introduction of the personified Laws may thus be seen as a device introduced with the intent of reminding the addressee of their civic obligations as recognized by the Athenians: they are the Laws that guarantee their freedom and survival, but also, not the least importantly, the laws that every citizen swears to obey and uphold..$^{46}$ In recognizing the essential connection between the two dialogues, we should keep in mind that the issues they deal with are intrinsically connected to the preconceptions and assumptions ruling the fourth century Athens, assumptions Aristophanes and others were known to support and defend.

This is, then the issue of justice and injustice, the issue debated over and over again in the literature of the period: is one justified in acting unjustly in response to a manifest injustice? The question will haunt Plato in other works as well, yet, quite possibly, the Crito is the dialogue where it emerges with utmost poignancy. Colored by the issue of just vs. legal, an issue of paramount importance in a community ruled by the man-formulated law, the dialogue seems to furnish the Socratic answer both to the charge of impiety and corruption and to the challenge posed by the manifest injustice of the death sentence.

${ }^{45}$ Interestingly, the case of philosophy is considered by Young (1974) to be the only instance of Socrates' choosing to disobey the city's command. It seems to me, however, that Young failed to appreciate the fact that the refusal relies on Socrates' belief in the divine mandate, and it is hardly fitting (as we know from the Euthyphro) to claim that two supreme instances may be at odds with each other on a such a matter. On the logical complexities of Young's position compare McLaughlin 1976.

${ }^{46}$ A fact particularly true of any official and we know that Socrates acted as one of the Prytanoi in the year of the Arginusian affair. 


\section{BIBLIOGRAPHY:}

Allen, D.S., 2000, World of Prometheus. The politics of punishing in democratic Athens, Princeton.

BARker, A., 1977, “Why did Socrates refuse to escape”, Phronesis 22, pp. 13-28.

Bosтоск, D., 2005, “An Interpretation of Plato’s Crito”, in: R. Kamtekar (ed.) Plato's Euthyphro, Apology, and Crito, Lanham, pp. 210-228 [originally published in Phronesis 35 (1990), pp. 1-20]

Bravo, B., 1988, Wipszycka-Bravo, E. Historia starożytnych Greków, t. I, Warszawa.

Brickhouse, T., Smith, N., 2005, „Socrates and Obedience to the Law”, in: R. Kamtekar (ed.), Plato's Euthyphro, Apology, and Crito, Lanham, pp. 183-174 [originally published in Apeiron 18 (1984) 10-18].

Christ, M. R., 2001, “Conscription of hoplites in classical Athens”, CQ 51, pp. 398-422.

GAGARIN, M., 1986, Early Greek Law, Berkeley-Los Angeles.

Gernet, L., 2004, “Capital Punishment”, in: P. J. Rhodes (ed.) Athenian Democracy, Oxford, p. 132-158.

Greenberg, N. A., 1965, “Socrates' Choice in the Crito”, HSCPh 70, pp. 42-82.

HAnsen, M. H., 1991, Athenian Democracy in the Age of Demosthenes: Structure, Principles and Ideology, Oxford 1991 (I used the Polish translation by R. Kulesza, Demokracja ateńska w czasach Demostenesa, Warszawa 1999).

HARRIS, W.V., 2002, Restraining Rage. The Ideology of Anger Control in Classical Antiquity, Harvard.

Harte, V., 2005, „Conflicting Values in Plato's Crito”, in: R. Kamtekar (ed.) Plato's Euthyphro, Apology, and Crito, Lanham, pp. 229-259 [originally published in AGPh 81 (1999), pp. 117-147].

Knox, B. M. W., 1964, The Heroic Temper. Studies in Sophoclean Tragedy, Berkeley-Los Angeles-London.

Konstan, D., 2006, The Emotions of the ancient Greeks. Studies in Aristotle and Classical Literature, Toronto.

Kraut, R., 1984, Socrates and the State, Princeton.

McLaughlin, R. J., 1976, „Socrates on Disobedience: a response to Gary Young” Phronesis 21, pp. $185-197$.

Mikalson, J. D., 1991, Honor Thy Gods. Popular Religion in Greek Tragedy, Chapel Hill-London.

Nightingale, A. W., 1992, „Plato’s Gorgias and Euripides' Antiope: a study of generic transformation”, ClAnt 11, pp. 121-141.

Ober, J., 1998, Political Dissent in Democratic Athens. Intellectual Critics of the Popular Rule, Princeton.

Penner, T., 1997, „Two notes on the Crito: the importance of the many and Persuade or Obey”, CQ 47, pp. 133-147.

Penner, T., 2005, „Socrates”, in: Ch. Rowe, M. Schofield (eds.), The Cambridge History of Greek and Roman Political Thought, Cambridge, pp. 164-189.

REEve, C. D. C., 2005, The Trials of Socrates: Six Classic Texts, Indianapolis.

Royle, T., 1999, Crimea. The Great Crimean War 1854-1856, London.

Sauve Meyer, S., „Plato on the Law”, in: H. H. Benson (ed.), A Companion to Plato, Malden-Oxford-Carlton, pp. 373-387.

Siewert, P., 1977, „The Ephebic Oath in Fifth Century Athens” JHS 97, pp. 101-111.

VAN'T Wont, P. E., 2010, “Solon's Law on Stasis. Promoting Active Neutrality”, CQ 60, pp. 289-301.

Young, G., 1974, „Socrates and Obedience”, Phronesis 19, pp. 1-29. 
JOANNA KOMOROWSKA /Warsaw /

\section{Why Not Escape? On the Hosiotes in Plato's Crito}

While the article discusses the factors that motivated Socrates' decision in the Crito, it emphasizes the possible cultural import of the choice undertaken in the aftermath of the political upheavals in the late fifth century. It is also argued here that as Plato's dialogue were written in the period that followed the renewal of the Athenian politeia, it should be perceived as having its roots both in the historical reality of its narrative focus (i.e. Socrates' trial) and in the then reality of Plato's Athens (i.e., its political stability dependent on the ephebic oath).

Plato, Socrates, the ephebic oath, civil obedience. 